\title{
IMPACT OF BIOTECHNOLOGY ON PRODUCTION AND FEED REQUIREMENTS OF DAIRY COWS AT PASTURE
}

S. R. Davis, E. R. Thorn, P. J. L'Huillier and A. M. Bryant Ruakura Dairy Research Centre, MAF, Hamilton

Abstract

Application of the technologies of genetic engineering in the dairy industry will begin within 5 years, probably with the use of bovine somatotropin as a lactationstimulant. There are several other likely developments which may manipulate the animal, the plant or the rumen micro-organism to increase or diversify production or to decrease milking frequency. To take full advantage of increased potential milk production, ways to minimise the seasonality of feed supply must be developed.

\section{INTRODUCTION}

Recent advances in recombinant DNA technology (genetic engineering) have greatly extended the applications of biotechnology. These advances have been made, in particular, with the techniques involved in gene identification, isolation, cloning and transfer (see McConnell 1986).

The dairy industry may benefit in several ways from application of these techniques. Broadly the prospects are:

1. Development of new techniques for early identification of genetically superior animals. A technique known as restriction fragment length polymorphism (RFLP) can be used in human prenatal diagnosis to detect DNA sequence changes associated with genetic diseases. This is achieved using enzymes which cut DNA at specific sequences (restriction enzymes). Changes in DNA may lead to appearance or disappearance of particular cutting sites and therefore the size of DNA fragments produced by the restriction enzymes may vary. The interpretation of the DNA fragment pattern and its association with productive traits may improve the rate of animal genetic improvement (Soller \& Beckman 1986).

2. Mammalian polypeptides produced via microbial fermentation may be used for the enhancement of growth, lactation, reproduction, etc. For example, synthesis of bovine somatotropin (BST; growth hormone) was not possible before the advent of recombinant DNA technology. Production of BST on a large-scale is now feasible and commercial sales of BST for administration to dairy cows to enhance milk production (by about 20\%) are likely within 5 years (Davis \& Bass 1984; Bauman \& McCutcheon 1985).

3. Production of transgenic animals (see Forrest \& Broad 1987, in this volume). It is feasible to transfer synthetic genes to fertilised eggs by direct injection. This technique was first used successfully for transfer and expression of a growth hormone gene in mice (Palmiter et a/. 1982). A number of research groups world-wide have been using the same techniques on domestic species including cattle (Church et al. 1985; Smith et al. 1987).

4. In ruminants, genetic modification of rumen microbes may be possible to promote fibre digestion and/or detoxify feed. Increasing the digestibility of fibre may be possible through genetic alteration of cellulolytic and lignin-degrading rumen microbes. Further, it may be feasible to seed the rumen with genetically modified bacteria capable of removing toxic principles found in New Zealand pasture. Work in these areas is proceeding overseas (Smith \& Hespell 1983; Teather 1985).

5. Genetic modification of plants. It is now feasible to transfer genes between plants and between animals and plants. The possibilities are vast but beyond the scope of the present review. The interested reader is referred elsewhere (Barton 8 Brill 1983; Llewellyn \& Brettell 1986). 
A requisite to the application of recombinant DNA technology in dairying is knowledge of the physiology of dairy cows and, in particular, which genes confer desirable attributes. The following discussion covers some of the physiological constraints under which dairy cows operate, the feasibility of overcoming these constraints and the likely impact of this new generation of dairy cows on pasture requirements and/or management. The prospective impact of BST usage on New Zealand dairying systems is also addressed.

\section{RELEVANT ASPECTS OF LACTATIONAL PHYSIOLOGY}

The rate of milk production is determined by the number of secretory cells in the udder and their productivity. Any manipulations which purport to increase milk yield must influence one or both of these parameters.

The number of secretory cells in the udder is determined during pregnancy (Davis et al. 1985). Growth of the udder ceases at calving when cell numbers are maximal. During lactation, cells are continually lost from the udder - a phenomenon which, in pan, determines the persistency of lactation (Davis et al. 1985). Thus the following basic options are available for increasing milk production through modification of mammary development.

1. Increase the number of secretory cells formed during pregnancy.

2. Reduce the rate of cell loss during lactation.

3. Induce udder growth during lactation.

The ability to modify mammary growth is potentially a useful means of enhancing milk production. Indeed, higher levels of production in high breeding index Jersey cows is associated with increased mammary development during pregnancy (Davis et al. 1985). Progress in the hormonal manipulation of mammary development is unlikely until more is known of the hormones involved in the quantitative control of mammary growth and regression. Thus the annual pregnancy cycle must suffice for the present as sole "treatment" to enhance udder growth.

Secretory cell loss from the udder occurs throughout lactation and is reflected in a decline in empty udder volume of around $50 \%$ during the first 20 weeks of lactation (Davis et al. 1985). However, little is known of factors which might reduce the rate of cell loss.

Secretory cell productivity is regulated by feed intake and nutrient supply to the udder (Davis \& Collier 1985) and hormonal influences. It is through increased cell productivity that materials such as BST are thought to enhance lactation. BST will likely be the first lactation stimulant of this nature in the "market place". However, there are several other methods through which the mechanism of action of BST can be exploited, using related peptides or a variety of immunological approaches.

While manipulation of milk production by hormonal means is feasible, a further area of interest, which is particularly relevant to New Zealand dairying, is that of milking frequency. A reduction in milking frequency while maintaining productivity would have major repercussions on the work load and life style of dairy farmers. One of the major constraints to maintaining production under extended milking intervals is the capacity of the udder to store milk - a capacity which at present is about 18-20 hours worth of production (Davis et al. 1987). This capacity can be increased by reducing the volume of milk output by reducing water output and thereby increasing the concentration of milk solids. The selection, by conventional methods, of animals with a high milk solids' content would be slow and probably to the detriment of progress in other production traits. It may be possible to identify animals producing milk of a high milk solids' content and output (mutants?) and use rapid multiplication methods (multiple ovulation and embryo transfer, Seidel 1984) to develop a nucleus herd of high-producing animals milked once daily. The use of gene injection into embryos may also be an option to modify the effect of genes which control water output in milk.

\section{EFFECTS OF BOVINE SOMATOTROPIN ON LACTATION}

One of the first products of recombinant DNA technology to affect the Dairy Industry wil be BST - produced by bacterial fermentation. The potency of recombinant derived BST has 
been examined in long term trials carried out over the last 4-5 years, Increases in milk

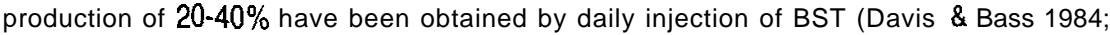
Bauman \&McCutcheon 1985) into concentrate fed cows. One trial with cows at pasture in Australia indicated that milk production was increased by $17 \%$ by daily injection of pituitary-extracted BST (Peel et al. 1985).

Of major importance with regard to the effect of BST on lactation is the fact that BST increases the gross efficiency of feed conversion into milk. This effect occurs in conjunction with a rise in feed intake of $10-15 \%, 4-6$ weeks after the onset of treatment (Bauman et al. 1985).

The increased cell productivity produced by BST treatment is of a similar magnitude to over 25 years of selection of Friesian cows for production (Davey ef al. 1983). Thus one attitude to the adoption of BST technology in dairying is that BST represents an acceleration in the rate of gain in productivity -25 years of genetic improvement arriving by syringe.

\section{Potential for Integration of EST into New Zealand Dairying}

Controlled release preparations of BST will likely be used to enhance milk production in cows within five years. Whether such preparations become available in New Zealand will depend on economics and the acceptance of milk products from BST treated cows in overseas markets. Both of these factors are unknown at present. However, it is pertinent to consider how the application of BST may be profitably integrated into the New Zealand dairy industry.

Campbell \& Bryant (1978) suggested that the major constraint to increased dairy production from pasture is the physiologically attainable yield of pasture dry matter. An increase in potential milk output would reinforce this concept. Further, the predominance of ryegrass/white clover pastures means peaks of pasture production in October/November followed by a major trough in summer.

The three basic options which might be considered to exploit this enhanced level of cow performance are:

1. Persist with present pasture species and employ increased conservation coupled with stocking rate reduction to even out feed supply.

2. Grow annual crops.

3. Develop/employ pasture species capable of sustained high yield independent of season. Reduction of stocking rate coupled with strategic administration of BST would maintain or increase milk output per farm while reducing winter feed requirements.

Growing annual crops has been suggested previously (Campbell \& Bryant 1978; Taylor \& Hughes 1978) but the costs involved have not permitted widespread adoption of this practice. The work of Rogers \& Robinson (1984) in Australia showed that high levels of milk production $(20-22 / / d)$ could be maintained throughout summer for cows fed white clover compared to ryegrass (14-I $5 / / \mathrm{d}$ ) and it is this need to increase summer production which is probably most advantageous with regard to supporting the lactation-stimulating effect of BST.

If year-round, high levels of milk production become feasible then it will be necessary to develop or employ pasture species capable of sustained, high yield, independent of season. The development of these plants may or may not require recombinant DNA techniques, but given the likely time scale of animal improvement it is important that some progress is made towards a reduction in seasonal variation in feed supply over the next $10-15$ years.

\section{CONCLUSIONS}

Substantial improvements in dairy cow performance are in prospect. The notion of hormonally/genetically modified cows producing $1 \mathrm{~kg}$ milkfat per day for 365 days of the year, yet only require milking once daily, is not idle speculation. The uncertainties relate to the time scale and desirability of these changes and improvement in the feed supply, in particular to enhance winter and summer feed production.

Improvements in cow performance will only be fully realised if the necessary feed 
supplies can be provided while maintaining the relative cost advantage which New Zealand dairying presently has over its competitors.

Some of these developments may reduce New Zealand's competitive advantage in the economics of milk production. This will occur if the application of these new technologies is more appropriate and effective in concentrate-fed cows.

As well as gains in productivity, recombinant DNA technology provides a means of reducing the costs and effort of dairy production, for example through reduced milking frequency and may also increase the diversity of products derived from milk. For example, the production of valuable pharmaceuticals via mammary synthesis and secretion has been suggested (Wagner 1987) and is actively being researched.

Finally, the above is only a brief overview of some of the developments which may occur over the next 20 years. There will likely be advances in other areas of relevance to dairying such as disease control and milking machine performance which will add to the productivity of the New Zealand dairy farm.

\section{References}

Barton K.A., Brill L.J. 1963. Prospects in plant genetic engineering. Science 219: 671-676.

Bauman DE.. McCutcheon S.N. 1985. The effects of growth hormone and prolactin on metabolism. Chapter 23. In: Milligan L.P., Grovum W.L., Dobson A. (Ed.). Control of digestion and metabolism in ruminants. Proceedings Sixth International Symposium on Ruminant Physiology. Reston Publishing Co., Reston, Virginia, USA.

Bauman D.E., Eppard P.J., DeGeeter M.J., Lanza G.M. 1985. Responses of high-producing dairy cows to long-term treatment with pituitary somatotropin and recombinant somatotropin. Journal of Dairy Science 68: 1352-1362.

Campbell A.G., Bryant A.M. 1978. Pasture constraints on dairy production. Proceedings of the Agronomy Society of N.Z. 8 : $115-118$.

Church R.B., Schaufele F.J., Meckling K. 1986. Embryo manipulation end gene transfer in livestock. Canadian Journal of Animal Science 65: 527-537.

Davis S.R., Bass J.J. 1994. Prospects for the stimulation of lactation and growth of ruminants by the administration of growth hormone and related molecules. Proceedings of the N.Z. Society of Animal Production 44: 91-97.

Davis S.R., Collier R.J. 1985. Mammary blood flow and regulation of substrate supply for milk synthesis. Journal of Dairy Science 68: 1041-1058.

Davis S.P., Hughson G.A., Bryant A.M., MacKenzie D.D.S. 1985. A physiological basis of genetic improvement in milk production of Friesian and Jersey cows. Proceedings of the N.Z. Society of Animal Production 45: 21-25.

Davis S.R., Fan V.C., Henderson H.V. 1987. Relationship of udder capacity of Friesian and Jersey cows to yield reduction under extended milking intervals. In Proceedings of the 4th Animal Science Congress of the Asian-Australasian Association of Animal Production Societies, Hamilton. N.2. p. 151.

Davey A.W.F.. Grainger D., MacKenzie D.D.S.. Flux D.S., Wilson G.F.. Brookes I.M., Holmes C.W. 1963. Nutritional and physiological studies of differences between Friesian cows of high and low genetic merit. Proceedings of the N.Z. Society of Animal Production 43: 67-70.

Llewellyn D., Brettell R. 1986. Potential for genetic manipulation to improve the production of crop and pasture plants. Reviews in Rural Science 6: 163-I 75

McConnell D.J. 1966. Methods and achievements of genetic engineering: prospects in agriculture. A review. Livestock Production Science 15: 109-1 31

Palmiter R.D., Brinster R.L., Hammer R.E., Trumbauer M.E., Rosenfeld M.G., Birnberg NC.. Evans A.M. 1982. Dramatic growth of mice that develop from eggs microinjected with metallothionein -growth hormone fusion genes. Nature (London) 300:61 I-615.

Peel C.J., Sandles L.D.. Quelch K.J.. Herrington A.C. 1985. The effects of long-term administration of bovine growth hormone on the lactational performance of identical twin dairy cows. Animal Production 41: 135-142

Rogers G.L., Robinson I.R. 1984. Whole lactation production of cows grazing white clover or perennial ryegrass. Dairy Production Research Report, Victoria Department of Agriculture and Rural Affairs, Ellinbank. pp. 146149.

Seidel G.E. 1984. Applications of embryo transfer and related technologies to cattle. Journal of Dairy Science 67 2786-2796.

Smith C.J., Hespell R.B. 1983. Prospects for development and use of recombinant deoxyribonucleic acid techniques with ruminal bacteria. Journal of Dairy Science 66: 1536-I 546.

Smith C.. Meuwissen T.H.E.. Gibson J.P. 1987. On the use of transgenes in livestock improvement. Animal Breeding Abstracts $55: 1-10$.

Soller M., Beckmann J.S. 1986. Restriction fragment length polymorphisms and animal genetic improvement. Reviews in Rural Science 6: 10-18.

Taylor A.O., Hughes K.A. 1976. Conservation based forage crop systems for major or complete replacement of pasture. Proceedings of the Agronomy Society of N.Z. 8: $161-166$.

Teather R.M. 1985. Application of gene manipulation to rumen microflora. Canadian Journal of Animal Science 65: 563-574.

Wagner T.E. 1987. Prospects for the use of mammalian gene transfer in animal agriculture. In Proceedings of the 4th Animal Science Congress of the Asian-Australasian Association of Animal Production Societies, Hamilton, N.Z. pp. 115-I 18. 